\title{
PEMANFAATAN APLIKASI WHATSAPP DALAM PEMBELAJARAN PENDIDIKAN AGAMA ISLAM DI ERA PANDEMI COVID-19
}

\author{
H. Asep Awaluddin1), Samsudin ${ }^{2}$ \\ 1)UNU Surakarta, ${ }^{1}$ STIT Islamiyah KP Paron Ngawi \\ 1) Asepawaluddin9@gmail.com, ${ }^{2}$ Samsudinsamsudin231@gmail.com
}

\begin{abstract}
Abstrak. Pandangan dasar yang dijadikan titik tolak Pendidikan Agama Islam adalah bahwa aspek keagamaan yang menjadi nilai moral dalam segala bidang keilmuan yang berkaitan dengan masalah yang saat ini dihadapi oleh masyarakat. Di era pandemi Covid-19 ini pembelajaran Pendidikan Agama Islam tidak boleh mengalami kemandekan. Oleh karena perlu solusi praktis dengan memanfaatkan perkembangan teknologi informasi. E-learning berbasis internet diyakini menjadi hal terpenting guna mencapai tujuan pembelajaran saat ini dan masa yang akan datang.Adapun progam salah satu aplikasi yang sering digunakan adalah Whattsapp dengan fungsi fitur percakapan grup yang dimilikinya. Hal ini sebagai jawaban atas belum dibukanya sekolah tatap muka di era new normal yang sedang berlangsung sekarang ini.
\end{abstract}

Kata Kunci: pandemi, Pendidikan agama islam, e-learning

Abstract. The basic view that is used as the starting point for Islamic Religious Education is that the religious aspect is a moral value in all scientific fields related to the problems currently faced by society. In this era of the Covid-19 pandemic, Islamic Religious Education learning should not stagnate. Therefore we need practical solutions by utilizing the development of information technology. Internet-based $e$ learning is believed to be the most important thing to achieve current and future learning goals. One of the most frequently used applications is WhatsApp with its group conversation feature function. This is in response to the unopened face-to-face school in the current new normal era.

Keywords: pandemic, Islamic religious education, e-learning

\section{PENDAHULUAN}

Pada hakikatnya Inovasi Pendidikan Agama Islam merupakan usaha untuk mencari bagaimana rencana dan pengaturan mengenai tujuan, isi, dan bahan pelajaran serta cara yang digunakan sebagai pedoman penyelenggaraan kegiatan pembelajaran yang sesuai dengan perkembangan dan kebutuhan untuk mencapai tujuan tertentu dalam suatu lembaga. Inovasi dapat diartikan sebagai sesuatu yang baru dalam situasi sosial yang digunakan untuk menjawab atau memecahkan suatu permasalahan. Lahirnya inovasi karena ada permasalahan yang harus diatasi, dan upaya mengatasi permasalahan tersebut melalui inovasi atau pembaharuan. Inovasi ini harus merupakan hasil pemikiran yang original, 


\section{QRPDEN \\ Jurnal Manajemen Pendidikan Islam}

INSTITUT AGAMA ISLAM SUNAN KALIJOGO MALANG

P-ISSN 2622-9293 / E-ISSN 2721-9658

Volume 3 Nomor 1 Juni 2021

kreatif, dan tidak konvensional. Penerapannya harus praktis dan di dalamnya terdapat unsurunsur kenyamanan dan kemudahan. ${ }^{1}$

Pendidikan secara umum merupakan salah satu cara untuk mengembangkan potensi diri seseorang juga pribadinya, dengan pribadi dan potensi yang baik maka seseorang bisa memberi manfaat kepada kehidupan yang berada disekitarnya, seperti yang telah sampaikan Rasulullah SAW bahwa sebaik-baiknya manusia adalah yang bermanfaat bagi manusia yang lain. Lingkungan yang memiliki masyarakat terdidik akan berkembang dengan baik dan akan memiliki kehidupan yang baik juga. Kegiatan mendidik bukan hanya peran dunia pendidikan atau institusi pendidikan saja tetapi disetiap tempat pada elemen masyarakat dimanapun juga harus melakukan kegiatan mendidik, karena mendidik adalah tugas setiap manusia bukan hanya tugas tenaga pendidik saja, hal ini diingatkan oleh Allah SWT didalam kitabnya Al- Quran surat Al-'Asr ayat ketiga "saling menasehatilah dalam kebenaran dan saling menasehatilah dalam kesabaran". ${ }^{2}$

Sebagai bagian dari masyarakat yang bernaung dibawah pemerintahan Negara Kesatuan Republik Indonesia, maka setiap individu masyarakat haruslah peduli, memberikan perhatian dan mengambil peran untuk terwujudnya tujuan pendidikan nasional yang tertuang dalam UU no. 20 tahun 2003 yang isinya: "Pendidikan nasional berfungsi mengembangkan kemampuan dan membentuk watak serta peradaban bangsa yang bermartabat dalam rangka mencerdaskan kehidupan bangsa. Bertujuan untuk berkembangnya potensi peserta didik agar menjadi manusia yang beriman dan bertakwa kepada tuhan yang maha esa, berakhlak mulia, sehat, berilmu, cakap, kreatif, mandiri, dan menjadi warga negara yang demokratis serta bertanggung jawab". ${ }^{3}$

Lebih fokus pada Pendidikan Agama Islam selain sebagai sebuah disiplin ilmu dalam bidang pendidikan juga merupakan peran bagi tercapainya tujauan pendidikan itu sendiri. Karena penekanan Pendidikan Agama Islam bukan hanya pada internalisasi nilai-nilai teori saja tetapi juga harus didukung platform e-chatting guna melakukan kegiatan belajar mengajar di era pandemi covid-19 ini. Dimana terjadi pembatasan-pembatasan atas segala bentuk interaksi sosial. Para guru dan siswa adalah individu-individu yang berperan besar didalam Pendidikan Agama Islam dalam mewujudkan tujuan pendidikan Nasional. Mereka

${ }^{1}$ Ni'mawati, Qiqi Yulianti, “Proses Inovasi Kurikulum: Difusi dan Diseminasi Inovasi, Proses Keputusan Inovasi”, Jurnal Miskat STAI Siliwangi Bandung Pascasarjana UIN Sunan Gunung Djati Bandung, Volume 05, Nomor 02 Desember 2020, Hal. 82.

${ }^{2}$ QS. Al'ashr (103) : 3 Nasional

${ }^{3}$ Republik Indonesia, Pasal 3, Undang-Undang No 20 Tahun 2003 Tentang Sistem Pendidikan 
adalah agen-agen terdekat pemerintah dalam mewujudkan tujuan nyata pendidikan.Pendidikan Agama Islam memiliki peran lebih kuat pada pembentukan watak yang menjadikan manusia beriman, bertakwa, berakhlak mulia, demokratis dan bertanggung jawab. Bagaimana peran para pendidik agama Islam dalam mewarnai hidup dan kehidupan ini dengan nilai-nilai Ketuhanan, nilai-nilai sang pencipta alam semesta, baik didalam kehidupannya ataupun kehidupan orang-orang disekitarnya, baik dilingkungan sekolah, keluarga ataupun masyarakat di era pandemi covid-19 ini?.

\section{METODE PENELITIAN}

Dalam penelitian ini adalah penelitian kualitatif deskriptif dengan pengumpulan data berbasis kepustakaan, wawancara dan pengamatan langsung di lapangan. Studi kepustakaan dilaksanakan dengan membaca, menelaah dan mencatat berbagai literatur atau bahan bacaan yang sesuai dengan pokok bahasan, kemudian disaring dan dituangkan dalam kerangka pemikiran secara teoritis. Teknik ini dilakukan guna memperkuat fakta untuk membandingkan perbedaan dan atau persamaan antara teori dan praktek yang sedang penulis teliti terkait masalah pendidikan dan perkembangan teknologi informasi. ${ }^{4}$

\section{HASIL DAN PEMBAHASAN}

Memasuki era kenormalan baru atau populer dangan jargon New Normal menjadi momentum besar bagi insan pendidikan untuk merefleksikan diri. Pasalnya gelombang Covid-19 selama lebih dari satutahun ini telah mengahantam infrastuktur pendidikan secara masif. Selama pandemic pendidikan kita menjalani interaksi sosial baru yaitu pendidikan dalam jaringan (daring). Hal ini sejalan dengan instruksi dari Kementerian Pendidikan dan Kebudayaaan, semua sistem pendidikan bertumpu pada sistem jaringan dengan segala perangkat yang mendukungnya. Di saat semua jarak dibatasi baik melalui social distancing maupun physical distancing, komunikasi jejaring internet menjadi aspek dominan ketika keterisoliasian manusia untuk pencegahan merebaknya wabah Covid-19. Sebagai konsekuensi logis, ruang kelas-kelas itu telah bermigrasi dari ruang sosial langsung menjadi ruang sosial virtual. 5

${ }^{4}$ Kartini Kartono, Pengantar Metodologi Research (Bandung : ALUMNI, 1998), hlm.78

5 Siti Rohmaturrosyidah Ratnawati dan Wilis Werdiningsih, "Pemanfaatan E-Learning Sebagai Inovasi Media Pembelajaran PAI di Era Revolusi Industri 4.0", Jurnal Pendidikan Islam Vol. 5, No 2, 2020; 199-220, Hal. 200. 


\section{PH<PDENIR<P \\ Jurnal Manajemen Pendidikan Islam}

INSTITUT AGAMA ISLAM SUNAN KALIJOGO MALANG

P-ISSN 2622-9293 / E-ISSN 2721-9658

Volume 3 Nomor 1 Juni 2021

Hal ini sejalan dengan gejala global termasuk di dalamnya Indonesia telah memasuki era revolusi industri 4.0 yang ditandai dengan cepatnya perkembangan pola digital economy, artificial intelligence, internet of Things (IoT), big data, robotic, dan fenomena disruptive innovation.Hasil survey yang dilakukan oleh Asosiasi Penyelenggara Jasa Internet Indonesia (APJII) menyatakan bahwa pada tahun 2016, jumlah pengguna internet di Indonesia telah mencapai 132,7 juta jiwa.4 Kemudian mengalami kenaikan sebesar 10,56 juta jiwa pada tahun 2017 sehingga mencapai 143,26 juta jiwa atau setara dengan 54,68\% dari total jumlah penduduk Indonesia. ${ }^{6}$ hingga kuartal II tahun 2020 jumlah pengguna internet mencapai 196,7 juta atau 73,7 persen dari populasi. Jumlah ini bertambah sekitar 25,5 juta pengguna dibandingkan tahun lalu. Angka ini tentunya terus mengalami kenaikan pada tahun-tahun yang akan datang. Hal tersebut tentu memberikan pengaruh terhadap setiap kegiatan personal dan sosial manusia, tidak terkecuali dalam proses pendidikan.

Berdasarkan hasil pengamatan sederhana, dapat tergambarkan adanya dinamika sikap, perilaku dan kecenderungan minat generasi milenial hari ini saat berinteraksi dengan dunia internet dalam kaitannya dengan dunia pendidikan. Secara umum, kebanyakan dari mereka lebih senang dan tertarik untuk mendapatkan informasi berbasis visual dengan mengakses berbagai macam platform seperti website, YouTube, aplikasi dan media sosial dari pada harus monoton melalui narasi ceramah dari guru atau teks buku cetak pelajaran mereka. Tidak diragukan lagi bahwa mayoritas dari generasi milenial hari ini juga sangat piawai bereksplorasi dan berselancar di dunia maya untuk mencari informasi tertentu ketimbang pasif terperangkap di perpustakaan konvensional atau di kelas dengan sistem pembelajaran yang teacher-centered. Mereka lebih bersemangat dan merasa nyaman untuk belajar secara kolaboratif dalam praktik nyata atau secara peer to peer melalui jejaring sosial (menggunakan social learning platform). Sebagaimana terobosan pemanfaatan IT dalam pelayanan masyarakat yang telah dijalankan di pemerintah kabupaten Banyuwangi. ${ }^{7}$

Berkaitan dengan hal tersebut, maka sudah semestinya perkembangan teknologi informasi dan komunikasi saat ini bisa dimanfaatkan dengan baik dan semaksimal mungkin untuk menunjang efektifitas proses pendidikan. Demikian juga halnya dengan Pendidikan Agama Islam (PAI) yang sangat memungkinkan mendapat sentuhan dari teknologi informasi

\footnotetext{
hal.201.

${ }^{6}$ Siti Rohmaturrosyidah Ratnawati dan Wilis Werdiningsih, "Pemanfaatan E-Learning ...,

7 Teguh Yuwono, Laila Kholid Alfirdaus, D. Ghulam Manar, “Semua Berawal dari IT:
} Terobosan Banyuwangi dalam Menata Ulang Tatakelola Pemerintahan", POLITIKA: Jurnal Ilmu Politik Vol.11, No. 2, 2020, hal. 149. 


\section{QRPDE \\ Jurnal Manajemen Pendidikan Islam}

INSTITUT AGAMA ISLAM SUNAN KALIJOGO MALANG

P-ISSN 2622-9293 / E-ISSN 2721-9658

Volume 3 Nomor 1 Juni 2021

dan komunikasi dalam proses pembelajarannya. Pemberian materi dan pelaksanaan proses belajar dapat dilakukan dengan memanfaatkan teknologi berbasis internet.

Hal ini tentu akan mampu mendukung seorang guru dalam menyampaikan materi ajar tentang Agama Islam kepada peserta didiknya. Terlebih jika dilihat dari sisi penerapannya secara umum, pembelajaran PAI selama ini cenderung masih bersifat monoton, kaku, terpaku pada buku teks bacaan, kurang inovatif, dan kurang memanfaatkan pesatnya perkembangan teknologi, sehingga pembelajaran pun cenderung membosankan. Tentu hal ini juga akan berdampak pada kurang efektifnya ketercapaian tujuan pembelajaran PAI itu sendiri. Terlebih lagi karakteristik peserta didik yang dididik hari ini sudah jauh berbeda dari generasi sebelum-sebelumnya, sehingga pendekatan dan media pembelajaran yang lebih inovatif dan progresif sangatlah dibutuhkan untuk mengakomodir minat mereka. ${ }^{8}$

Sebagai alternatif penyelesaian masalah tersebut sekaligus untuk mengakomodir pergerakan yang kian cepat dari perkembangan teknologi dan informasi di era revolusi industri 4.0 ini, maka, proses pembelajaran dan setiap komponen yang ada dalam mata pelajaran PAI perlu dikembangkan dengan mentransformasikannya ke dalam bentuk virtual ataupun electronic. Hal ini juga tidak terlepas dari bergesernya kebutuhan masyarakat sekarang yang menganggap kecepatan dalam mengakses informasi dan pengetahuan terkini menjadi hal yang hampir menyamai kebutuhan sekunder. Proses transformasi tersebut diharapkan dapat menjembatani antara realitas yang ada dengan idealitas dalam proses pendidikan, pastinya tanpa mengesampingkan nilai-nilai pendidikan yang ada di dalamnya. Salah satu alternatif pengembangan pembelajaran PAI yang dapat dilakukan di era revolusi industri 4.0 ini adalah pembelajaran elektronik atau yang sering dikenal dengan istilah $e$ learning. 9

Inovasi sering dikaitkan dengan perubahan, tetapi tidak setiap perubahan dapat dikategorikan sebagai inovasi. Menurut Rogers, inovasi adalah suatu gagasan, praktik, atau objek benda yang dipandang baru oleh seseorang atau kelompok adopter lain. Kata "baru" bersifat sangat relatif, bisa karena seseorang baru mengetahui, atau bisa juga karena baru mau menerima meskipun sudah lama tahu. Lahirnya inovasi karena ada permasalahan yang harus diatasi, dan upaya mengatasi permasalahan tersebut melalui inovasi atau pembaharuan. Inovasi ini harus merupakan hasil pemikiran yang original, kreatif, dan tidak

8 Moh. Tohet, "Modernisasi Pendidikan Islam (Telaah Pemikiran Fazlur Rahman)”, Jurnal Pendidikan Agama Islam, (https://ejournal.unuja.ac.id/index.php/edureligia/index), April 2021.

${ }^{9}$ Siti Rohmaturrosyidah Ratnawati dan Wilis Werdiningsih, "Pemanfaatan E-Learning ..., hal.202. 


\section{คКคDEMIKค \\ Jurnal Manajemen Pendidikan Islam}

INSTITUT AGAMA ISLAM SUNAN KALIJOGO MALANG

P-ISSN 2622-9293 / E-ISSN 2721-9658

Volume 3 Nomor 1 Juni 2021

konvensional. Penerapannya harus praktis dan di dalamnya terdapat unsur-unsur kenyamanan dan kemudahan.

\section{Pengertian dan Karakteristik E-Learning}

Istilah e-learning terdiri dari huruf $e$ yang merupakan singkatan dari kata electronic dan learning yang berarti pembelajaran. Maka, secara sederhana e-learning bisa berarti kegiatan pembelajaran yang memanfaatkan atau menggunakan perangkat elektronik. Adapun mengenai definisi e-learning sendiri sebetulnya sangatlah beragam, akan tetapi secara umum keragaman definisi tentang e-learning ini bertolak dari dua pandangan dasar mengenai $e$ learning, yaitu: 10

1. Electronic based-learning, yakni kegiatan pembelajaran yang memanfaatkan teknologi informasi dan komunikasi, terutama perangkat yang berupa elektronik. Artinya, tidak hanya internet, melainkan semua perangkat elektronik seperti film, video, kaset, OHP, Slide, LCD Projector, tape, dan lain-lain sejauh menggunakan alat elektronik.

2. Internet based, yaitu pembelajaran yang menggunakan fasilitas internet yang bersifat online sebagai instrument utamanya. Artinya, memiliki persepsi bahwa e-learning haruslah menggunakan internet yang bersifat online, yaitu fasilitas komputer yang terhubung dengan internet. Artinya, pembelajar dalam mengakses materi pembelajaran tidak terbatas jarak, ruang, dan waktu, bisa di mana saja dan kapan saja (anywhere and anytime).

Definisi e-learning menurut The American Society for Training and Development (ASTD) yang dikutip oleh Rusman adalah serangkaian aplikasi dan proses yang mencakup pembelajaran berbasis web, pembelajaran berbasis komputer, ruang kelas virtual dan digital. Banyak dari ini disampaikan melalui internet, intranet, pita audio dan video, siaran satelit, TV interaktif, dan CD-ROM. Pengertian e-learning bervariasi tergantung pada organisasi dan cara penggunaannya tetapi pada dasarnya melibatkan sarana komunikasi elektronik, pendidikan, dan pelatihan. ${ }^{11}$

Sedangkan persepsi bahwa e-learning merupakan internet based learning juga didukung oleh beberapa ahli, salah satu diantaranya adalah Rosenberg yang berpendapat bahwa e-learning merupakan penggunaan dan pemanfaatan teknologi internet untuk mengirimkan serangkaian solusi dan informasi yang mampu memperluas pengetahuan dan hal.204.

${ }^{10}$ Siti Rohmaturrosyidah Ratnawati dan Wilis Werdiningsih, "Pemanfaatan E-Learning ...,

${ }^{11}$ Ibid., hal.204. 
meningkatkan keterampilan. Selanjutnya, pandangan tersebut juga didukung oleh pendapat Fernando Alonso sebagaimana dikutip oleh Lantip Diat Parsojo dan Riyanto yang mengatakan "Learning Management System (LMS) atau platform e-Learning adalah perangkat lunak khusus yang dimaksudkan untuk menawarkan pendidikan virtual dan atau lingkungan pelatihan secara online". ${ }^{12}$

Berpijak pada kedua persepsi dasar e-learning serta beberapa definisi dari beberapa ahli mengenai e-learning, dapat disimpulkan bahwa e-learning memiliki dua konsep pengertian, yaitu e-learning dalam pengertian luas dan e-learning dalam pengertian sempit. Dalam pengertian luas, e-learning dapat dimaknai sebagai kegiatan pembelajaran dengan memanfaatkan berbagai macam dan jenis media elektronik seperti video, televisi, komputer, radio, tape, LCD projector, telepon, dan lain-lain, sedangkan dalam pengertian sempit, $e$ learning dapat diartikan sebagai proses pembelajaran yang menggunakan fasilitas internet sebagai medianya. Oleh karena itu, e-learning dalam arti sempit juga seringkali dikenal dengan istilah pembelajaran daring atau dalam jaringan (online learning/online course) dan virtual learning.

Berdasarkan uraian singkat mengenai pengertian e-learning tersebut di atas, dapat dipahami bahwa pada intinya, e-learning adalah proses atau kegiatan pembelajaran dengan menggunakan berbagai jenis alat dan media elektronik, khususnya gawai (gadget), komputer atau laptop dan juga internet yang bertujuan untuk mendukung proses pembelajaran baik sebagai suplemen (tambahan), komplemen (pelengkap), ataupun substitusi (pengganti). Di era pandemi covid-19 ini e-learning bukan hanya menjadi tambahan (suplemen), namun lebih dari itu ada kecenderungan menjadi pengganti dari metode pembelajaran secara langsung atau tatap muka yang masih belum dibuka sampai pada kuartal ketiga tahun 2021 ini.

Dalam penjelasannya saat mengajar di Universitas Nadhlatul Ulama Surakarta pada pertengahan bulan Februari 2021, Ki Supriyoko penasihat Majlis Luhur Taman Siswa sekaligus sekretaris Dewan Pengawas Pendidikan Nasional menyatakan bahwa beliau lebih senang menggunakan program aplikasi whattsapp dan whattsapp grup untuk mengajar para

${ }^{12}$ Ibid., hal.205. 
mahasiswa, karena whattsapp tidak mengharuskan sinyal yang kuat dan hemat kuota internet. ${ }^{13}$

Istilah e-learning sering juga disebut dengan distance learning atau pembelajaran jarak jauh. Hal ini disebabkan karena memang pada awalnya, e-learning sengaja didesain untuk memfasilitasi pembelajaran jarak jauh yang dilaksanakan sebagai alternatif pembelajaran karena adanya keterbatasan waktu, ruang, serta biaya dalam mengikuti pembelajaran konvensional. Maka, dalam prosesnya, guru dan murid berada di tempat yang terpisah, sehingga bahan ajar y ang disampaikan berupa media elektronik yang disampaikan melalui internet. Media yang dimaksud bisa berupa website, chatting, video conference, dan lain sebagainya

E-learning dipandang mampu menunjang sebuah proses pembelajaran dan pendidikan karena e-learning mempunyai setidaknya beberapa karakteristik diantaranya adalah: 1) interaktivitas (interactivity), yakni ketersediaan jalur komunikasi yang lebih variatif, baik secara langsung (synchronous) seperti video call, messenger, dan chatting; maupun secara tidak langsung (asynchronous) seperti mailing list, forum, atau buku tamu; 2) kemandirian (independency), yaitu terciptanya pembelajaran yang lebih terpusat pada siswa (student-centered learning) karena adanya fleksibilitas baik dalam aspek penyediaan waktu, tempat, pengajar, maupun bahan ajar; 3) aksesibilitas (accessibility), yakni kemudahan untuk mengakses berbagai macam sumber belajar melalui jaringan internet dengan akses yang lebih cepat dan luas daripada pendistribusian sumber belajar secara konvensional; dan 4) pengayaan (enrichment), materi-materi yang disajikan melalui e-learning dapat berperan sebagai pengayaan bagi pembelajar. ${ }^{14}$

\section{Sejarah dan Perkembangan E-Learning}

Perkembangan e-learning sendiri beriringan dengan perkembangan dunia Teknologi Informasi dan Komunikasi. Hal ini dimulai dari dikenalnya komputer oleh masyarakat secara luas, terutama para akademisi, yang kemudian mulai dimanfaatkan dan dikembangkan untuk kepentingan pendidikan dengan tujuan untuk meningkatkan efektifitas dan efisiensi proses pendidikan. E-learning merupakan salah satu produk integrasi dan inovasi Teknologi

13 Wawancara dalam kuliah program Pascasarjana S3 dengan Prof Dr. Ki Supriyoko, S.D.U, M.Pd., Dosen Tetap Program Doktor Fakultas PAI Universitas Nahdlatul Ulama Surakarta, Februari 2021. hal.206.

${ }^{14}$ Siti Rohmaturrosyidah Ratnawati dan Wilis Werdiningsih, "Pemanfaatan E-Learning ..., 
Informasi dan Komunikasi (TIK) ke dalam dunia pendidikan. Sebagai salah satu produk integrasi tersebut, e-learning diharapkan mampu membuka babak baru dalam dunia pendidikan yang mampu memberikan kemudahan, kenyamanan, keefisienan, dan keefektifan belajar bagi pembelajar.

Dalam pada itu, e-learning telah mengalami perkembangan yang cukup pesat dari masa ke masa. E-learning pertama kali diperkenalkan oleh Universitas Illinois di UrbanaChampaign dengan menggunakan sistem Computer-Assisted Instruction (CAI) dan komputer bernama PLATO. Sejak saat itu, perkembangan e-learning dapat digambarkan sebagai berikut. Tahun 1990 merupakan era CBT (Computer Based Training), era di mana aplikasi e-learning yang bisa dioperasikan dalam Personal Computer (PC) ataupun berbentuk kemasan CD-ROM mulai bermunculan.15. Selanjutnya, tahun 1994 merupakan era pengembangan Computer Based Training menjadi paket-paket CBT yang lebih menarik, seperti penggunaan animasi untuk bahan ajar, dan lain-lain.

Pada tahun 1997 adalah era berkembangknya LMS (Learning Management System). Sejak tahun ini, perkembangan teknologi internet sudah mulai dimanfaatkan dalam kegiatan pembelajaran, akan tetapi masih merupakan tahap awal dari proses tersebut. Berlanjut ke tahun 1999 yang merupakan era Aplikasi e-learning berbasis Web. Pada tahun 2000, banyak perusahaan di bidang bisnis yang mulai mengadopsi e-learning sebagai pusat pelatihan bagi pekerjanya. Tools untuk e-learning sudah mulai banyak ragam yang bermunculan. Kemudian mulai tahun 2010 hingga sekarang, media sosial mulai banyak digunakan, sehingga $e$ learningsemakin terinspirasi dengan social media karena dianggap mampu memberikan inovasi dan suasana belajar yang lebih fun. Diantara beberapa contoh media sosial yang dimaksud diantaranya adalah Youtube, Twitter, Instagram, Facebook, Skype, Hangout, dan Whattaps. ${ }^{16}$

Perlu diketahui juga bahwa pada awalnya, e-learning ini didesain dan dikembangkan untuk keperluan pembelajaran jarak jauh (distance learning) yang merupakan bentuk alternatif pembelajaran yang dimaksudkan untuk menyelesaikan permasalahan keterbatasan waktu dan tempat yang dihadapi dalam proses pembelajaran di dunia pendidikan, sebagaimana yang juga terdapat di Negara kita, Indonesia, di mana e-learning mulai dimanfaatkan dan dikembangkan sebagai fasilitas penunjang pembelajaran jarak jauh seiring hal.207.

${ }^{15}$ Siti Rohmaturrosyidah Ratnawati dan Wilis Werdiningsih, "Pemanfaatan E-Learning ..., hal.207.

${ }^{16}$ Siti Rohmaturrosyidah Ratnawati dan Wilis Werdiningsih, "Pemanfaatan E-Learning ..., 
dengan dikeluarkannya Surat Keputusan Menteri Pendidikan Nasional No. 07/U/2001 tentang PTJJ (Perguruan Tinggi Jarak Jauh) yang secara spesifik mengizinkan penyelenggaraan pendidikan melalui Pendidikan Jarak Jauh dengan memanfaatkan teknologi informasi. Lalu, seiring dengan perkembangan zaman, e-learning sudah mulai digunakan untuk menunjang pembelajaran tatap muka (konvensional), khususnya di tingkat Perguruan Tinggi (PT), Sekolah Menengah Atas (SMA), dan Sekolah Menengah Pertama (SMP). ${ }^{17}$

\section{Fungsi atau Peran E-Learning bagi Kegiatan Pembelajaran}

Dalam kaitannya dengan kegiatan pembelajaran, e-learning dapat berfungsi sebagai beberapa kategori peran. Beberapa fungsi e-learning terhadap kegiatan atau proses pembelajaran diantaranya adalah sebagai suplemen(tambahan), komplemen (pelengkap), dan substitusi (pengganti). Untuk lebih jelasnya, berikut ini adalah penjelasan masing-masing fungsi e-learning bagi kegiatan pembelajaran:18

1. E-learning sebagai suplemen (tambahan) E-learning dikatakan berfungsi sebagai suplemen (tambahan) apabila peserta didik atau pembelajar mempunyai kebebasan untuk memilih antara memanfaatkan materi yang tersedia pada e-learning atau tidak. Artinya, peserta didik tidak diharuskan atau diwajibkan untuk mengakses platform $e$ learning dan juga tidak diharuskan untuk memanfaatkan materi yang tersedia di dalamnya melainkan hanya bersifat opsional. Akan tetapi, peserta didik yang mau memanfaatkannya tentu akan memiliki tambahan ilmu, wawasan, pengetahuan dan informasi yang lebih luas bermanfaat. Contohnya adalah setelah dijelaskan tentang rukun sholat secara lengkap guru memberikan tugas kepada para siswa untuk mencari gambar atau video gerakan sholat di YouTube kemudian merangkumnya dalam bentuk tulisan.

2. E-learning sebagai komplemen (pelengkap) E-learning berfungsi sebagai komplemen (pelengkap), jika materi yang tersedia pada platform e-learning ditujukan dan diprogramkan untuk menjadi pelengkap dan pendukung bagi materi pembelajaran yang diterima oleh peserta didik dari pembelajaran tatap muka di kelas. Hal tersebut juga berarti bahwa materi atau latihan-latihan soal yang tersedia pada platform e-learning yang digunakan, diprogramkan sebagai materi pengayaan (reinforcement) bagi peserta

\footnotetext{
17 Keputusan Menteri Pendidikan Nasional Republik Indonesia Nomor 07/U/2001 Tentang Penyelenggaraan Program Pendidikan Tinggi Jarak Jauh

18 Husnul Khatimi, "Mengenal E-Learning Sebagai Salah Satu Bentuk Kegiatan Pembelajaran”, Jurnal Info Teknik, Volume 7 No. 2, Desember 2006
} 
didik yang mampu menguasai dan memahami materi yang mereka dapatkan dari kegiatan belajar mengajar (KBM) tatap muka di kelas dengan cepat (fast learners). Selain itu, materi e-learning juga bisa diarahkan sebagai program remedial bagi peserta didik yang mengalami kesulitan dalam menguasai dan memahami materi pelajaran dari KBM di kelas (slow learners) dengan memberikan kesempatan kepada mereka untuk mengakses materi-materi e-learning yang sudah disediakan bagi mereka, agar mereka bisa mempunyai waktu dan kesempatan lebih untuk lebih memahami materi pelajaran yang telah dipelajari bersama guru di dalam kelas. Contohnya adalah setelah menjelaskan satu keutamaan berpuasa guru memerintahkan siswa untuk mencari di mesin pencari online tentang keutamaan puasa yang kedua, ketiga dan seterusnya. Kemudian siswa dimintah menuliskannya di buku.

3. E-learning sebagai substitusi (pengganti) Sedangkan peranan e-learning sebagai substitusi (pengganti) dalam pembelajaran konvensional adalah untuk membantu mempermudah para peserta didik untuk mengelola kegiatan pembelajarannya agar sesuai dengan waktu dan aktivitas lainnya. Dalam konteks ini, setidaknya ada tiga opsi model kegiatan pembelajaran yang bisa dipilih, yaitu: a) tatap muka sepenuhnya (konvensional); b) melalui internet sepenuhnya; c) perpaduan atau kombinasi antara tatap muka dan melalui internet. ${ }^{19}$ Inilah yang terjadi di era pandemi covid-19 saat ini, yaitu pembelajaran menggunakan jaringan (dalam jaringan) internet. Bisa memanfaatkan google classroom, google meet, zoom, youtube, facebook ataupun aplikasi media sosial yang sangat banyak pilihannya, seperti halnya aplikasi yang paling sering digunakan adalah aplikasi whattsapp dengan grup whattsapp-nya.

Dari penjelasan di atas, dapat kita pahami bersama bahwa e-learning tidak hanya dapat dimanfaatkan untuk merealisasikan pembelajaran jarak jauh (distance learning), tapi juga bisa dijadikan sebagai sarana penunjang dan pendukung bagi kegiatan pembelajaran tatap muka, untuk mata kuliah atau mata pelajaran apapun termasuk Pendidikan Agama Islam (PAI), baik di lembaga pendidikan formal maupun non-formal.

\section{Kelebihan dan Kekurangan E-Learning}

Penggunaan dan pemanfaatan e-learning dalam pembelajaran sebetulnya tidak bisa terpisahkan dari penggunaan internet itu sendiri. Artinya, tentu terdapat sisi kelebihan dan

${ }^{19}$ Supriyanta, Pengembangan E-Learning Sebagai Pelengkap Pembelajaran Tatap Muka Pada Program Diploma Tiga Amik BSI Yogyakarta, http:// ejournal.bsi.ac.id. 9 April 2021. 
juga kekurangan di dalamnya. Internet menjadi suatu opsi dan alternatif yang sangat strategis bagi kegiatan pembelajaran dengan terciptanya kemudahan untuk mengakses berbagai informasi secara luas kapan pun dan di mana pun. Munir menyebutkan bahwa sekurang-kurangnya ada tujuh kelebihan dan manfaat e-learning, khususnya e-learning berbasis internet sebagaimana terperinci di bawah ini:20

1. Tersedianya fasilitas e-moderating yang memungkinkan guru dan peserta didik untuk berinteraksi dan berkomunikasi dengan lebih mudah melalui fasilitas internet tanpa dibatasi oleh waktu, jarak, dan tempat.

2. Guru dan peserta didik dapat mengakses dan menggunakan bahan ajar atau petunjuk belajar yang terstruktur dan terjadwal melalui internet, sehingga kedua belah pihak bisa saling mengevaluasi sampai sejauh mana materi dan bahan ajar telah dipahami dan dikuasai.

3. Peserta didik bisa mempelajari atau me-review bahan ajar di mana pun dan kapan pun. Disamping itu, materi $e$-learning juga bisa disimpan di gadget, komputer, ataupun laptop sehingga peserta didik bisa lebih mudah untuk mengulang materi dan bahan ajar.

4. Jika peserta didik membutuhkan tambahan informasi seputar materi atau bahan ajar yang mereka pelajari, mereka dapat mengaksesnya secara langsung dan mudah melalui fasilitas internet.

5. Guru dan juga peserta didik dalam jumlah banyak sekalipun juga tetap bisa berdiskusi secara daring, sehingga mereka dapat menambah wawasan dan ilmu pengetahuan secara lebih mudah dan luas.

6. Peserta didik yang biasanya cenderung pasif menjadi lebih aktif

7. Relatif lebih efisien dari segi waktu, tempat, dan biaya.

Namun disisi lain, penggunaan dan pemanfaatan internet untuk pembelajaran atau $e$ learning tentu juga tidak terlepas dari kelemahan atau kekurangan yang diantaranya adalah: ${ }^{21}$

1. Interaksi dan komunikasi antara guru dan peserta didik atau bahkan antarpeserta didik menjadi berkurang, sehingga berpotensi memperlambat dan menghambat terbentuknya value dalam proses pembelajaran tersebut.

${ }^{20}$ Siti Rohmaturrosyidah Ratnawati dan Wilis Werdiningsih, "Pemanfaatan E-Learning ...,

21 Hamonangan Tambunan, Model Pembelajaran Berbasis E-Learning Suatu Ta 
2. Adanya kemungkinan untuk cenderung mengesampingkan aspek akademik, sikap, perilaku, atau aspek sosial peserta didik, dan sebaliknya justru memperhatikan aspek komersial atau bisnis. Hal tersebut sangat mungkin terjadi apabila pemanfaatan elearning justru difokuskan pada aspek teknologinya, dan bukan pada aspek pendidikannya.

3. Proses pembelajaran cenderung bercorak pelatihan daripada pendidikan.

4. Apabila dalam pelaksanaan e-learning guru kurang atau bahkan tidak menguasai metode, strategi, juga teknik pembelajaran berbasis e-learning, maka tentu hal tersebut akan menghambat proses pembelajaran itu sendiri.

5. Peserta didik yang tingkat kemandirian dan motivasi belajarnya rendah cenderung akan sulit atau bahkan gagal mencapai tujuan pembelajaran yang hendak dicapai.

6. Tidak semua tempat tersedia fasilitas internet atau jaringan yang memadai dan lancar.

7. Keterbatasan penguasaan media teknologi informasi dan komunikasi baik pada tenaga ahli, tenaga pendidik maupun peserta didik tentu juga akan mengurangi efektivitas penggunaan dan pemanfaatan $e$-learning itu sendiri.

\section{Pemanfaatan E-Learning di SD IT As-Salamah sebagai Inovasi Media Pembelajaran PAI di Era Revolusi Industri 4.0}

Perlu diakui bersama bahwa proses pembelajaran mata pelajaran PAI di banyak lembaga pendidikan di Indonesia hingga saat ini belum memanfaatkan kemajuan TIK secara maksimal untuk menunjang proses belajar peserta didik, termasuk dalam hal pemanfaatan $e$ learning sebagai salah satu produk perkembangan TIK. Institusi pendidikan yang sudah mulai menggunakan dan memanfaatkan e-learning untuk mendukung dan menunjang proses pembelajaran di dalamnya, khususnya untuk mata pelajaran PAI bisa dibilang masih belum terlalu banyak. Hal tersebut terjadi karena masih mengakarnya pandangan atau mindset bahwa PAI merupakan mata pelajaran yang sakral, sarat akan makna dan nilai, serta rumit, yang mengharuskan adanya pertemuan tatap muka (face to face) antara guru dan murid di setiap kegiatan pembelajaran. Eksistensi dan peran guru dalam pembelajaran, tidak akan mungkin mampu tergantikan oleh keberadaan media elektronik, sehingga mereka bersikukuh menolak pemanfaatan e-learning dalam bentuk apapun.

Namun, di sisi lain, sudah ada juga pihak-pihak yang sudah mulai menggeser paradigma tersebut dengan memulai untuk mencoba memanfaatkan dan mengembangkan $e$ learning sebagai penunjang proses pembelajaran PAI, yang salah satunya adalah SDIT As- 
Salamah Baturetno, Wonogiri, Jawa Tengah. E-learningyang digunakan adalah dengan menggunakan google classroom dengan satu alasan bahwa progam ini relatif tanpa gangguan dan tidak memerlukan banyak kuota data internet. Adapun dalam penugasan kepada para siswa guru PAI SDIT As-Salamah Baturetno memanfaatkan whattsapp grup, baik pada saat menyampaikan tugas ataupun saat para siswa mengumpulkan tugas menggunakan whattsapp grup tersebut.

Terbukti dalam hal ini, e-learning bisa menjadi pilihan solusi untuk menjawab permasalahan yang pembatasan kegiatan belajar secara langsung atau tatap muka, serta sekaligus jawaban atas permasalahan kurangnya jam pelajaran atau waktu yang dialokasikan untuk mata pelajaran PAI di lembaga pendidikan, padahal cakupan dan rincian materinya sangat banyak dan luas.

Selain itu, pemanfaatan e-learning juga bisa diarahkan dan ditujukan untuk mengakomodir karakteristik generasi milenial hari ini yang cenderung sangat dekat dan menyukai teknologi dan social media. Lebih daripada itu, Guru PAI SDIT As-Salamah juga menegaskan mengenai salah satu alasan mengapa beliau tanpa ragu memanfaatkan elearning sebagai media penunjang pembelajaran PAI di SDIT As-Salamah adalah karena tidak bisa dinafikan lagi bahwa PAI kini juga telah berada pada masa atau era revolusi industri 4.0 yang sangat berkaitan erat dengan abad 21 yang artinya

\section{PENUTUP}

Peran guru PAI dalam era pandemi covid-19 ini adalah dengan memusatkan diri dalam dukungan kemajuan dan perkembangan teknologi informasi dan komunikasi yang kian pesat di era revolusi industri 4.0 memang sudah seharusnya dimanfaatkan dengan maksimal oleh para pendidik PAI, yang salah satunya adalah dengan menerapkan sistem pembelajaran berbasis daring atau yang sering dikenal dengan istilah e-learning. Hal ini bertujuan untuk menjunjang proses pembelajaran PAI sehingga bisa menjadi lebih inovatif, tidak membosankan, menarik, tidak monoton, dan menyenangkan. Lebih dari pada itu, pembelajaran PAI berbasis e-learning juga mampu berperan sebagai alternatif model pembelajaran yang dapat mengantarkan generasi milenial saat ini untuk memperoleh materi, mengerjakan tugas dan melakukan penilaian atas hasil belajar para siswa. 


\section{DAFTAR PUSTAKA}

Al-Qur'an dan Terjemahannya. 2011. Jakarta : Cahaya Qur'an.

Hamonangan Tambunan.2021. Model Pembelajaran Berbasis E-Learning Suatu Tawaran Pembelajaran Masa Kini Dan Masa Yang Akan Datang, https://jurnal.unimed.ac.id, 09 April.

Kartono, Kartini.1998. Pengantar Metodologi Research. Bandung : ALUMNI.

Keputusan Menteri Pendidikan Nasional Republik Indonesia Nomor 07/U/2001 Tentang Penyelenggaraan Program Pendidikan Tinggi Jarak Jauh

Khatimi, Husnul. 2006. Mengenal E-Learning Sebagai Salah Satu Bentuk Kegiatan Pembelajaran. Jurnal Info Teknik, Volume 7 No. 2, Desember.

Ni'mawati, Qiqi Yulianti.2020. Proses Inovasi Kurikulum: Difusi dan Diseminasi Inovasi, Proses Keputusan Inovasi. Jurnal Miskat STAI Siliwangi Bandung Pascasarjana UIN Sunan Gunung Djati Bandung, Volume 05. Nomor 02 Desember 2020.

Rohmaturrosyidah, Siti. Ratnawati dan Werdiningsih, Wilis.2020. Pemanfaatan E-Learning Sebagai Inovasi Media Pembelajaran PAI di Era Revolusi Industri 4.0. Jurnal Pendidikan Islam Vol. 5, No 2

Supriyanta, 2021.Pengembangan E-Learning Sebagai Pelengkap Pembelajaran Tatap Muka Pada Program Diploma Tiga Amik BSI Yogyakarta, http:// ejournal.bsi.ac.id. 9 April.

Tohet, Moh. 2021. Modernisasi Pendidikan Islam (Telaah Pemikiran Fazlur Rahman), (https://ejournal.unuja.ac.id/index.php/edureligia/index), April 2021.

Undang-Undang Republik Indonesia, No 20 Tahun 2003 Tentang Sistem Pendidikan Nasional

Wawancara dalam kuliah program Pascasarjana S3 dengan Prof Dr. Ki Supriyoko, S.D.U, M.Pd., Dosen Tetap Program Doktor Fakultas PAI Universitas Nahdlatul Ulama Surakarta, Februari 2021.

Yuwono, Teguh. Kholid Alfirdaus, Laila. Ghulam Manar, D.2020. Semua Berawal dari IT: Terobosan Banyuwangi dalam Menata Ulang Tatakelola Pemerintahan, POLITIKA: Jurnal Ilmu Politik Vol.11, No. 2. 